\title{
MAJOR MUSLIM-CHRISTIAN DIALOGUE INITIATIVES SINCE 9/11
}

\author{
Simon Herrmann ${ }^{1, *}$ \\ ${ }^{1}$ Department of Aqidah and Islamic Thought, Academy of Islamic Studies, Universiti Malaya, 50603 Kuala \\ Lumpur, MALAYSIA.
}

\begin{abstract}
The events of 9/11 deepened tensions between the West and the Islamic world. But there were also Christians and Muslims who used the occasion to intensify dialogue with each other. In the 20 years since then, dialogue has taken place in many forms and settings. This article asks which large-scale dialogue initiatives between Muslims and Christians were started in the time since 9/11 and what their salient characteristics are. Using a historical and qualitative approach, it contributes to establishing a framework for Muslim-Christian dialogue by showing the developments and providing insights in the current status of the larger, widely visible Muslim-Christian dialogue initiatives. The first part introduces and describes seven such initiatives, ranging from conferences to centres, programs and individual persons. Using a deductive approach, initiatives are analysed according to the people involved, the time and location in which they took or take place, and the topics dealt with. The second part critically analyses the progression of these large-scale dialogue initiatives between Muslims and Christians. What stands out is their diversity and the fact that notable individuals and institutions of both religions have been involved as actors in the process. In a globalized world, what happens on the big stages also impacts what happens elsewhere. The precedence set by the initiatives introduced thus can serve to encourage and give credibility to the enterprise of Muslim-Christian dialogue in other contexts as well.
\end{abstract}

Keywords: Muslim-Christian dialogue; interreligious dialogue; dialogue initiatives

\section{Introduction}

The events of September 11, 2001 - or short, 9/11 -, had a significant impact on the world and international relations. They took place in a climate where scholars had already predicted a clash between Islam and the West (Huntington, 2016). Following the attack, U.S. President George W. Bush embarked on the War on Terror. Islamophobia was on the rise and relations between civilizations shaped by Islam and those shaped by Christianity were strained.

On the other hand, Muslim-Christian dialogue also gained momentum after these events (Johnston, 2016). Timothy Tennent (2007), a US-American Christian scholar,

\footnotetext{
* Corresponding author: simon-herrmann@gmx.net eISSN: 2636-9265 CUniversiti Malaya Centre for Civilisational Dialogue, 2021

DOI: https://doi.org/10.22452/KATHA.vol17no1.1
} 
writes how within weeks after 9/11 dialogue sessions sprung up in many different places. There was an eager interest among Christians to learn more about Islam and local Muslim leaders were invited for public conversations on the topic of religion and faith. However, dialogue initiatives did not remain on the local level only; some had a far wider, often international, scope.

Dialogue on the local level does not take place in a historical or ideological vacuum. Especially under the conditions of a globalized world, what takes place on the big stage sends signals into local communities. Therefore, this article reviews seven large-scale initiatives in the history of Muslim-Christian dialogue that started in the 20 years since 9/11. The thesis of this article is that the range of actors and initiatives today is more diverse than 20 years ago as a wider variety of people and institutions, both Muslim and Christian, have taken active roles in the dialogue process.

Christians as well as Muslims have laid out scriptural and theological reasons for their religious communities to participate in interreligious dialogue (e.g., Machado, 2019; Bakour, 2018). In addition to that, seeing others, from scholars to leaders to ordinary members of the religion, being involved and actively supporting dialogue can add to the courage and credibility of the undertaking in other contexts.

\section{Methodology}

The question this paper seeks to answer is: Which large-scale dialogue initiatives between Muslims and Christians were started in the time since 9/11 and what are their salient characteristics? The article aims to contribute to establishing a framework for Muslim-Christian dialogue initiatives in recent history by showing the developments and providing insights in the current status of the larger, widely visible MuslimChristian dialogue initiatives.

As with every historical study, the author must decide which episodes to include. The number of initiatives introduced here needed to be limited and could have been enlarged (see, for example, the initiatives listed by Weller, 2018). The selection made for this article, however, is not arbitrary. Some initiatives are milestones and are referenced in articles and books, some are too large to be overseen, some are significant in introducing new aspects or actors in the process and some are significant because of the status and potential impact the persons involved have. Some of the initiatives combine several of these aspects. The nets were cast wide and therefore, not only conferences, but also programs, centres and important persons are included, rendering it impossible to apply stricter or harder criteria for the selection than those just mentioned.

There is very little literature that reflects on some of the initiatives; therefore, the presentation will be descriptive first. Using a deductive approach, initiatives are analysed according to the people involved, the time and location in which they took or take place, and the topics dealt with. The progression of the dialogue between Muslims 
and Christians on the large scale and the diversity in various regards will be explicated in the critical reflection towards the end of the article.

\section{Intra-religious dialogue and interreligious dialogue}

Before looking at the different initiatives, it is important to note that frequently interreligious dialogue does not stand alone but is complemented and, more often, preceded by intra-religious dialogue. The often-heterogenic religious bodies within one religion need to come together to clarify their common basis and discuss how their commonalities and differences impact their engagement in interreligious dialogue. This prerequisite for interreligious dialogue is pointed out by Muslims (Shafiq \& AbuNimer, 2011) as well as Christians (World Council of Churches, 2016). There is clear evidence on both Christian and Muslim sides for this to have happened since 9/11: Representatives of the World Council of Churches (Protestant) gathered with those of the Pontifical Council for Interreligious Dialogue (Roman Catholic), and those of the World Evangelical Alliance (Evangelical) in 2006, 2007 and 2011, to discuss how witness and dialogue can respectfully take place in a multi-religious world. The document that resulted from these consultations, Christian Witness in a Multi-Religious World: Recommendations for Conduct (World Council of Churches et al., 2011), has become an often-quoted point of reference for Christians' relations with people of other faith. On the Muslim side the process started by King Abdullah II bin Al-Hussein of Jordan in 2004, leading to the intra-Muslim dialogue and the Amman Message (http://ammanmessage.com), deserves to be mentioned. Later, members of the royal Jordan family were behind the interfaith Common Word initiative described later. Likewise, the initiative of King Abdullah of Saudi Arabia to bring leaders of Islam together in June 2008 preceded the launching of the interfaith conference in Madrid later in the year (Islamic Educational, 2011).

\section{Survey of seven large-scale dialogue initiatives}

The presentation of the seven initiatives will start with two that have had a significant impact on the development of interreligious dialogue while having come to a conclusion. Next, three conferences will be introduced that have taken place on a relatively regular basis. Lastly, two contributions to Muslim-Christian dialogue will be presented that are strongly connected with the individuals that stand behind it.

\section{Fuller Theological Seminary's Conflict Transformation Program}

A significant initiative to foster dialogue between Muslims and Christians in the United States after 9/11 was the Conflict Transformation Program. Fuller Theological Seminary (Pasadena, CA) had received a grant from the U.S. Department of Justice (Woodberry, 2010). From 2003 to 2006, the evangelical ${ }^{1}$ seminary partnered with the

\footnotetext{
${ }^{1}$ Evangelicals are not a certain Christian denomination, but Christians who hold certain orthodox Christian beliefs. They emphasize God's revelation in the Bible as authoritative, Jesus' death on the cross as redemption, and the work of the Holy Spirit in transforming humans. Out of these core Christian beliefs, they also highlight the need to respond to the Gospel through a decision to follow Jesus Christ
} 
Salaam Institute for Peace and Justice at the American University in Washington, D.C., and the Islamic Society of North America for the implementation of the program. Mohammed Abu-Nimer and David Augsburger (2009), the latter being the chair of the program, described the purpose as follows: "to seek common practices, patterns, and pathways for conflict reduction, resolution, and transformation between faiths as well as to learn how to better resolve differences within our individual faith communities" (p. 12). They also describe how the initiative aimed to contribute to the dialogue on the local, practice-oriented level as well as on the scholarly level. On the community level, the program leaders created platforms, organized gatherings, and led talks between local religious leaders, such as imams and pastors. They also developed a manual used for conferences, where Christians and Muslims spent the weekend together and discussed issues pertaining to their faith.

On the scholarly level, two consultations were held, one in Washington, D.C. and another in Pasadena that resulted in a collection of essays (Abu-Nimer \& Augsburger, 2009) in which both Christian and Muslim scholars contributed and commented on each other's work. In this way, the dialogue of the two sessions was continued in the publication and made available for the interested public. Among the issues discussed are hot topics for Muslim-Christian relations, such as understanding war and peace and questions about witness, conversion and apostasy. Students of Fuller Seminary were also involved in the initiative and took up the baton by carrying out research about interfaith projects. A number of these student papers were also published. The book's title, Resources for Peacemaking in Muslim-Christian Relations (Woodberry \& Basselin, 2006), illustrates the wish to connect the academic world with the world where Muslims and Christians live their lives side by side.

\section{A Common Word Initiative}

When Pope Benedict XVI. addressed the University at Regensburg, Germany, on 12 September 2006 (Benedict XVI., 2006), little did he know that his lecture would spark anger and indignation among many Muslims. To illustrate the importance of reason in conjunction with faith, he used an example from the late $14^{\text {th }}$ century when the Byzantine emperor Manuel II conversed with an educated Persian. Benedict quoted the emperor who had said: "Show me just what Mohammed brought that was new, and there you will find things only evil and inhuman, such as his command to spread by the sword the faith he preached." While not making this statement his own, he agreed with Manuel II's conclusion, namely that "spreading the faith through violence is something unreasonable. Violence is incompatible with the nature of God and the nature of the soul." This was the only point he wanted to make. ${ }^{2}$ However one wants to interpret the Pope's speech, the least that can be said is that his example was chosen unwisely. It also provoked vehement protests in the Muslim world.

(conversion), sharing one's faith with others (evangelism), and having fellowship with other Christians; see: Stott (2003).

${ }^{2}$ See Footnote 3 of the aforementioned document, where the Pope tries to explain why he sees himself as having been misunderstood. 
As a response, a month after the Pope's lecture, 38 Muslim scholars and intellectuals, led by Prince of Jordan Ghazi bin Muhammad of Jordan, issued an Open Letter to His Holiness, the Pope, on 13 October 2006. They attempted to point out in a very gentle and polite way some factual mistakes in the lecture (Ghazi bin Muhammad, 2010). However, the response they received was not satisfactory. On 13 October 2007, 138 Muslim scholars and leaders wrote an Open Letter to leaders of Christian churches, everywhere, entitled: A Common Word between Us and You. Many of these 138 Muslims are scholars and leaders of high rank and together exercise influence over hundreds of millions of Muslims. The title of the document leans on Surah 3:64:

"Say: O People of the Scripture! Come to a common word between us and you: that we shall worship none but God, and that we shall ascribe no partner unto Him, and that none of us shall take others for lords beside God. And if they turn away, then say: Bear witness that we are they who have surrendered (unto Him)." (The wording here follows the Common Word declaration in Volf et al., 2010, p. 46; emphasis added.)

Their hope was to find common ground for dialogue with Christians on the unity of God, love of him and love of others which they saw as a basis of both religions. In retrospect, Gazi bin Muhammad (2010) clarifies the motive for launching A Common Word:

"We repeat that we had honestly ... only one motive: peace. We were aiming to try to spread peace and harmony between Christians and Muslims all over the world, not through governments and treaties but on the all-important popular and mass level, through precisely the world's most influential popular leaders - that is to say, through the leaders of the two religions. ... We were keenly aware, however, that peace efforts also required another element: knowledge. We thus aimed to spread proper basic knowledge of our religion in order to correct and abate the constant and unjust vilification of Islam, in the West especially." (p. 9)

Within days, many Christian leaders responded individually to the open letter, welcomed and endorsed it (www.acommonword.com/christian-responses). On 18 November 2007 a joined Christian response followed, titled Loving God and Neighbor Together: A Christian Response to 'A Common Word Between Us and You' (reprinted in Volf et al., 2010, pp. 51-75). It was published in the New York Times and was signed by almost 300 Christian theologians and leaders. ${ }^{3}$ The document is appreciative of the initiative taken by the Muslim leaders and affirms that love for God and neighbour are indeed central issues also for Christians. It highlights that there exists a common ground, even "in some of the fundamentals of faith" and expresses the hope that the

\footnotetext{
${ }^{3}$ Because Miroslav Volf, Director of the Yale Center for Faith and Culture at Yale Divinity School, was leading in this process, it is often also called The Yale Response.
} 
"undeniable differences" between the two religions will not be able to overshadow this "common ground upon which we stand together" (Volf et al., 2010, p. 53).

What followed next was a conference held from 28-31 July 2008 in Yale, attended by more than 150 Muslim and Christian leaders (Volf et al., 2010 also entails the proceedings from that gathering). The leaders were looking for common ground, tried to clarify misconceptions, but did so from a position of faith and openly pointed out areas in which they could not agree. Other conferences followed, articles and books were published, and a plethora of symposia, workshops, and local interfaith initiatives have arisen that were not officially coordinated by those who initially spearheaded the initiative (Ghazi bin Muhammad, 2010, p. 14). According to the initiative's website (www.acommonword.com), it became "the most successful Muslim-Christian interfaith initiative in history."

\section{Building Bridges Seminar}

The Building Bridges Seminar was first held in 2002 (within less than a year after 9/11) on the invitation of the Archbishop of Canterbury, who is the head of the Anglican Church (i.e., the Church of England). In 2012, the Berkley Center at Georgetown University, Washington, D.C., took over the lead. Georgetown University is a Catholic University. One of the scholars responsible for the project, David Marshall, works with the World Council of Churches (Protestant). Thus, the structural leadership of the seminar is in the hand of Christian scholars employed by Christian institutions which are affiliated with different denominations. Nevertheless, "[t]he dialogue is equally owned by both the Christians and Muslims involved" (Pratt, 2021, p. vii) evidenced by the fact that "[v]enue locations alternate between Christian and Muslim hosts with both faiths represented in the planning and organisation of each Seminar" (Pratt, 2021, pp. 10-11).

The gathering is relatively small, roughly 30 people, and consists of "Christian and Muslim scholars with deep commitment to their religion" who come together to discuss themes that are of significance for both faiths. The discussions entail the study of religious texts and theological reflection (The Building Bridges Seminar, 2018). Often, a Christian and a Muslim scholar provide their respective view on a particular topic with discussions following (Mosher, 2015, p. 513).

Getting to know each other personally during the weeklong seminar by sharing meals or going for a walk is an integral aspect of the seminar, as various participants point out in a video (Berkley Center, 2020). For Pratt (2021), who has recently undertaken an elaborate study of the Building Bridges Seminar, it demonstrates "the possibility and reality of deep interreligious engagement of these two faiths in the contemporary world" (p. vii).

Usually, a book is published with the proceedings of the seminar (Mosher, 2015, 521522). The themes since the inception of the Building Bridges Seminar are listed in table 
1 at the end of this article. The seminar planned for 2020 with the theme "Naming God" had to be postponed due to the Corona pandemic (Pratt, 2021, p. 11).

\section{Doha Interfaith Dialogue Conference}

A year after the Building Bridges Seminar was first convened, another yearly gathering was birthed in Doha, Qatar and goes back to an initiative of the Emir of Qatar at that time, Sheikh Hamad bin Khalifa al-Thani. He had invited the Building Bridges Seminar to be convened in Doha. So the first Doha Interfaith Dialogue Conference equals the second Building Bridges Seminar (Mosher, 2015, p. 513). From there on, the Doha conference developed independently. The conference aims to provide a platform for "those interested in interfaith and intercultural dialogue to address issues of concern to societies and to discuss challenges to ... peaceful coexistence between religions and multiculturalism." It also wants to "foster a culture of peace among human beings" (Doha International Center for Interfaith Dialogue, n.d.).

The first two conferences were only for Christians and Muslims, but starting from 2005, Jewish representatives were also invited. Number of participants grew from less than 100 in the first years to around 500 in 2016 and includes, in addition to representatives of the religions, also politicians and sometimes scientists, which is evidence for the broad scope of the conference. It is convened by the Doha International Center for Interfaith Dialogue (DICID, which was founded in 2007) and the Ministry of Foreign Affairs of Doha. It always takes place in one of the hotels in Qatar's capital. It is generally held annually, but in the past few years rather biannually, as table 2 shows.

A conference was planned for 2020 but had to be postponed due to the Corona pandemic. For the same reason, no conference could be held in 2021, but there are plans to hold the next conference as soon as feasible (DICID secretariat, personal communication, May 25, 2021).

In addition to holding these international conferences, the DICID is engaged in a whole range of other programs to support dialogue and also issues two journals. As the News section on its website shows, it also hosts roundtable discussions on contemporary issues, comments on current affairs, and receives delegations from other nations.

\section{International Conference on Youth and Interfaith Dialogue}

The third conference to be introduced here takes place in different cities in Nigeria, either every year or every other year. It is called International Conference on Youth and Interfaith Dialogue. It is convened by New Era Educational and Charitable Support Foundation (NEECDSI, www.newerasupportfoundation.org), sometimes in partnership with other organizations like the United Religions Initiative (URI, https://uri.org). There is no website specifically for the conference. Therefore, what is presented here had to be gathered from different sources on the internet. The description of the $4^{\text {th }}$ conference in 2012 gives insights into the purpose of the conference. It reads as follows: "The Conference brings together citizens, including 
representatives of CSOs and Faith-based groups within Nigeria and around the world, to promote and improve mutual respect between faiths and cultures and to support civil society and individuals who intend to reject violence and build our common future" (United Religions Initiative, 2012). The focus is on enhancing communication and relationship between members of different faiths, primarily through young people, as the invitation for the third conference states: "Youth - with international adult mentors - will successfully engage face to face, applying new tools of communication and creativity to then take back home to their schools, communities, and nations" ( $3 r d$ Annual International Conference on Youth and Interfaith Communication, 2011). Hands-on workshops where young people can learn to get in touch and communicate with people of other ethnicity and faith were also advertised.

While the conference was held annually from 2009 to 2015, there was a two-year gap until the next conference was held in 2018. The number of participants was somewhere between 250 for the first conference and slightly above 100 for the 2018 conference. Considering the religious clashes in Nigeria in recent years, the conference put a particular emphasis on countering violent extremism for its most recent three conferences. The themes for the conferences are listed in table 3 .

According to Emmanuel Ivorgba (personal communication, May 25, 2021), director and convener of the conference, funding challenges did not allow the continuation after 2018. However, NEECDSI and URI carry on their work by hosting small group interfaith dialogue programs. Through initiatives like an Interfaith Academy (www.newerasupportfoundation.org/interfaith-academy), they attract young people in universities and colleges across Nigeria.

\section{Pope Francis}

The Pope is the representative of all Roman Catholic Christians, currently numbering roughly 1.2 billion people. When the current Pope, Francis, was elected in 2013, he became quickly known for his concern for the poor and disadvantaged. In addition, he has frequently shown the importance of interreligious dialogue in his words and deeds, a fact also recognized by Muslim scholars (see, for example, Siddiqui, 2018). A few highlights about his work for interreligious, especially Christian-Muslim relations must suffice:

In 2014, when visiting the President of the Department for Religious Affairs in Turkey, he stated his fundamental convictions about interreligious dialogue:

"Good relations and dialogue between religious leaders have, in fact, acquired great importance. They represent a clear message addressed to their respective communities which demonstrates that mutual respect and friendship are possible, notwithstanding differences." (Benedict XVI., 2014)

He makes it clear that religious leaders are role models for the faithful. It is also significant that he not only speaks of tolerance but mutual respect and friendship. 
A second example comes from 2018 when, on Holy Thursday, ${ }^{4}$ Pope Francis went to a prison outside the Vatican to wash the feet of twelve inmates. Among the men were eight Catholics, two Muslims, a Buddhist and a member of the Orthodox Church (Hitchen, 2018). Undoubtedly, this gesture must be interpreted as an act of humility and a sign of openness toward people of other faith.

The last example comes from a survey of the Pope's travels. In 2019 he visited the United Arab Emirates, Morocco, and Bulgaria (Catholic News Agency, n.d.). In each of these visits, the topic of dialogue between the religions was high on the agenda. The visit to the UAE was outstanding as it was the first visit of a Pope to the Arabian Peninsula. The Pope was hopeful that the promotion of peace, based on human brotherhood, had made progress through his visit. During his time there, he also signed a document on human fraternity with the Grand Imam of al-Azhar, Ahmed el-Tayeb (who also is one of the signatories to A Common Word) and was also able to celebrate a mass at the stadium in Abu Dhabi that was attended by around 150,000 people (Brockhaus, 2019).

As the first Pope ever, Francis visited Iraq in March 2021. He first met with the head of Iraq's Shiite community, Grand Ayatollah Ali al-Sistani, for an almost hour-long, private conversation (Catholic News Agency, 2021b). Later, he gathered with Christian, Muslim and Jewish representatives for an interreligious meeting. They met at Ur, which according to all three religions is the birthplace of Abraham (Catholic News Agency, 2021a). The religious leaders together appealed for harmony and fraternity between members of the different faiths.

\section{King Abdullah bin Abdulaziz and KAICIID}

In 2008 King Abdullah bin Abdulaziz of Saudi Arabia sponsored the Madrid Interfaith Conference to which Christian and Jewish as well as Hindu and Buddhist representatives were invited. Around 300 religious leaders gathered and underlined the need for dialogue for the well-being of people in society in the Madrid Declaration. Among other points, it stressed that "[d]ialogue is a necessity of life and is one of the most important means of getting to know and cooperate with others for the wellbeing of everybody" (The Madrid Declaration, 2008).

In 2012, the King Abdullah bin Abdulaziz International Centre for Interreligious and Intercultural Dialogue (KAICIID) was opened in Vienna, Austria. It is a joint intergovernmental organization with Saudi Arabia, Austria, and Spain as stakeholders. However, Centre's initiative and funding comes from King Abdullah of Saudi Arabia. The Centre convened a conference in 2014 with representatives of different religions from Iraq, Syria, and other countries in the Middle East under the theme United Against Violence in the Name of Religion. They denounced "all violence in the name of religion,

\footnotetext{
${ }^{4}$ This is the day before Good Friday on which Christians remember the death of Jesus Christ. According to the Bible, on the evening before, which is Holy Thursday, Jesus washed his disciples' feet and celebrated the Last Supper with them.
} 
and have called on the international community to protect religious and cultural diversity in Iraq and Syria" (KAICIID Dialogue Centre, n.d.).

In 2017, the KAICIID founded a network of Christian and Muslim Faculties and Institutions in the Arab World to find opportunities for cooperation and interreligious exchange programs for institutions of religious education (KAICIID Dialogue Centre, 2017). Another platform for interreligious cooperation and dialogue in the Arab World was launched with 23 high-ranking religious leaders in Vienna in early 2018 (KAICIID Dialogue Centre, 2018).

Although the Middle East and the Arab World are the main focus of the KAICIID, it also has various programs to prevent violence, facilitate dialogue and foster social cohesion in Vienna, the Central African Republic, Nigeria, India and Myanmar (www.kaiciid.org/what-we-do).

While the activities have seen the support of many organizations, institutions and religious leaders, there have also been critical voices from the beginning of Saudi Arabia's initiatives for interreligious dialogue, based on questions over the country's stance towards religious freedom and human rights. Although KAICIID claims that it is an international and interreligious organization and therefore " $[i]$ ts activities cannot ... be identified with any particular State" (KAICIID Dialogue Centre, 2019), it is undoubtedly true that Saudi Arabia is the central agent in the cooperation, as the name of the Centre already indicates. On the $12^{\text {th }}$ of June 2019, the Austrian parliament decided to pull out as a member of the organization and close the centre in Vienna, which caused many religious leaders and beneficiaries of KAICIID's program to voice their support for the Centre. In recent developments, Faisal bin Muammar, the Secretary General of KAICIID, announced that the Centre would relocate to another city; all parties took the decision unanimously (KAICIID Dialogue Centre, 2021).

\section{Critical reflection}

The review of the major interreligious dialogue initiatives of the past two decades clearly shows the wide range of large-scale initiatives for dialogue between Muslims and Christians. While 9/11 gave an impetus to some of the initiatives, it cannot account for all. The International Conference on Youth and Interfaith Dialogue in Nigeria has its own history, and the context of Nigeria plays a considerable part in its existence. The rise of the so-called Islamic State in the Middle East has frequently been mentioned as highlighting the need for dialogue in the Arab World initiatives of KAICIID. Growing tensions, often either outright religious or with religious undertones, have often contributed to the growth of interreligious dialogue initiatives. While uncertainties will not be eliminated entirely, sensible voices on both sides work for deescalation, understanding, and fraternity and make their voices heard.

Noteworthy is the diversity of approaches and initiatives, especially regarding the people and institutions that have been involved. Five aspects are of particular importance: 
First, there is diversity in those who initiated the dialogue. The initiators range from churches and Christian universities to Muslim state-funded organizations and nonprofit organizations. Specific individuals also play an important role. The early initiatives - Fuller's Conflict Transformation program and the Building Bridges seminar - have its roots in Christian institutions. However, it cannot be overseen that over the years, Muslims have taken a more and more active role in interreligious dialogue as the following snapshots from the literature illustrate: In 2011, Sallie King (2011) observed that it was often Christians who promoted dialogue. She remarked that "greater non-Western leadership would be welcomed, [but] ... has not been forthcoming" (p. 104). In this context, it is clear that "non-Western" also includes "nonChristian." Two years later, in a comment to the Common Word Initiative, Daniel Madigan (2013) wrote: "It is new and slightly discomfiting for the PCID [i.e., the Vatican based Pontifical Council for Interreligious Dialogue - S.H.] to recognize that its Muslim partners are now taking some control of the dialogical process" (p. 252). Then, again two years later, Turan Kayaoglu (2015) remarked that " $t \mathrm{t}] \mathrm{he}$ interfaith dialogue agenda is now well-established in contemporary Muslim thought and practice" (p. 22). These quotes indicate that there has been a movement to more initiative taking regarding interreligious dialogue among Muslims in recent years. Muslims are not only responding to the invitation of Christians. They are themselves taking a much more active role as the Common Word initiative, the DICID and the KAICIID clearly indicate.

Second, there is a growing consensus that deep commitment to one's faith is no hindrance to interreligious dialogue. People with strong faith commitments can still seek common ground, good relationships, and the good of society in dialogue with each other. Especially the growing stream of evangelical Christianity needed time to get involved in interreligious dialogue, mainly because they feared that they had to give up some of the convictions about their faith that they held dearly. For many evangelicals, the interreligious dialogue was long seen closely related to a pluralist theology of religions as proposed, for example, by John Hick (1982). However, initiatives like the Conflict Transformation program at Fuller Seminary or the Common Word initiative made it tangible that they did not have to compromise their faith to be engaged in interreligious dialogue. Whereas religions have often been seen as the cause of conflict, those involved in interreligious dialogue have become convinced that, especially as people committed to their faith, they can play an essential part in seeking peace and understanding in this world.

Next, Muslim-Christian dialogue is not something that has just a few proponents on the fringes of the religions. The initiatives introduced here have involved significant institutions and people of rank on both sides. Neither Christians nor Muslims have a single organisation or person who could represent them all. But with one of the most prominent-evangelical seminaries (Fuller), a substantial Muslim umbrella organisation (Islamic Society of North America), institutions of high reputation (Yale Divinity school), and renowned Muslim scholars involved (to name just one, the former Grand 
Mufti of Egypt and President of Al-Azhar University, Shaykh Ahmad Muhammad AlTayeb), the initiatives gained both influence and credibility. The Pope is in a unique position as the head of the largest Christian denomination and has enormous influence; so does King Abdullah as the Custodian of the Two Holy Mosques. They both use their influence to foster interreligious dialogue.

Fourth, part of the diversity of the introduced initiatives is that not only religious people and bodies are among the initiators, but that in part, states and governments are involved. The KAICIID bears the name of the Saudi king and was set up as an intergovernmental centre. The conference in Doha is jointly conducted by DICID and the Ministry of Foreign Affairs of Doha. Pope Francis is, strictly speaking, also the head of state of the Vatican, and while his political powers are limited, he meets with political representatives and speaks into society many times. As a matter of fact, governments have recognized the need for interreligious dialogue and often are involved directly or indirectly. An example of the more indirect involvement is the grant given to Fuller Seminary by the Justice Department to carry out the Conflict Transformation Program. When state agencies are involved in interreligious dialogue, there is a risk that political and economic interests or quests for power take undue prominence. Kayaoglu (2015), for example, writes that two of the reasons Saudi Arabia is such an active player in interreligious dialogue are "to substantiate Saudi leadership claims among Muslims and to engage with non-Muslim political and religious leaders as the mouthpiece of the Muslim world" and "to improve the Kingdom's image in the West regarding its record of human rights and religious freedom" (p. 20). Likewise, the Australian government's pulling out of the KAICIID could also be seen as politically motivated. While government involvement in interreligious dialogue carries problematic aspects, there is also the hope for it to have more significant and more direct influence on politics and public policies, often intertwined with religious issues.

Lastly, the dialogue initiatives reflect a wide range of modes and happen on different levels. While the Building Bridges seminar takes place solely on a scholarly level, in the Conflict Transformation Program it was purposely planned from the start that scholars, clergy as well as people on the grass-roots level should be involved; in the Common Word Initiative the debate was first held on the scholars' level (but with the common believers in mind) and later trickled down to the local level, albeit partly without being planned so. While some of the KAICIID's programs are oriented towards scholars, others are engaged with people at the grassroots. The International Conference on Youth and Interfaith Dialogue entails vital hands-on elements and includes political and social decision-makers.

Out of the five modes of dialogue that Kimball (2009, section Modes of Dialogue) proposes, the initiatives introduced here best cover the modes of institutional dialogue, theological dialogue, and dialogue in community/dialogue of life. The other two modes he mentions, parliamentary dialogue and spiritual dialogue, are less represented. However, the latter is included when, for example, the Pope and other religious 
representatives said a prayer when gathering near Abraham's birthplace. One aspect not often mentioned in the literature could be dubbed "symbolic dialogue." This would include actions like washing the feet of a Muslim by the Pope, the permission granted by the Emir of the UAE to perform a mass on the Arabic Peninsula, or the gathering of representatives of the Abrahamic religions at the birth place of Abraham. In all of these actions, the symbolic character carries much weight for interreligious relations.

\section{Conclusion}

The description of the initiatives, together with the critical reflection made it clear that there has been an increase in dialogue initiatives in the past two decades and that they came in a vast variety. Leading figures of Islam and Christianity have not only been proponents of dialogue but have themselves been driving forces in the process. What has also become apparent - and might sound like a silly truism - is that initiatives always need someone to initiate them; they do not create themselves. Someone needed the vision for Muslims and Christians to come together and take steps toward this aim. This is also true for the initiatives to be sustained. While some had their point in time and served the needs of that time (e.g., the Conflict Transformation Program initiated by Fuller Theological Seminary or the Common Word Initiative), others are planned to continue, but are hindered by funding problems (International Conference on Youth and Interfaith Dialogue), the Corona crisis (Building Bridges Seminar, Doha Interfaith Dialogue Conference), or political dissension (KAICIID).

While it needs energy, commitment and courage to keep the dialogue alive or to start new initiatives, those who are interested in doing so - may it be on the grassroots level, among the clergy, scholars or high-ranking representatives of the two religions - will find examples of prominent figures within their own religion, and likely even within their denomination, who led the way and can serve as examples and, if necessary, also as justification for their steps in moving dialogue between the two faiths further. 


\section{References}

3rd Annual International Conference on Youth and Interfaith Communication (2011). http://2011interfaithconference.cfsites.org/

Abu-Nimer, M., \& Augsburger, D. W. (Eds.). (2009). Peace-building by Between, and Beyond Muslims and Evangelical Christians. Lexington Books.

Bakour, B. (2018). Islam and the West: From Clash to Dialogue. KATHA, 14(1), 1-31. Benedict XVI. (2006). Faith, Reason and the University: Memories and Reflections. http://w2.vatican.va/content/benedictxvi/en/speeches/2006/september/documents/hf_benxvi_spe_20060912_university-regensburg.html

Benedict XVI. (2014). Address of the Holy Father: Visit to the President of the Diyanet at the Department for Religious Affairs. https://w2.vatican.va/content/francesco/en/speeches/2014/november/documen ts/papa-francesco_20141128_turchia-presidenza-diyanet.html

Berkley Center. (2020). The Building Bridges Seminar. https://youtu.be/uLyk72vUVM?list=PLvFmBRVUSWDE1aEHmrWtPslAon7qahkhj

Brockhaus, H. (2019). Pope Says UAE Trip Was 'New Page' in Dialogue between Christians, Muslims. Catholic News Agency, CNA (06. February 2019). https://www.catholicnewsagency.com/news/pope-says-uae-trip-was-newpage-in-dialogue-between-christians-muslims-13898

The Building Bridges Seminar. (2018). Berkely Center for Religion, Peace \& World Affairs at Georgetown University. Retrieved 24. June 2019 from https://berkleycenter.georgetown.edu/projects/the-building-bridges-seminar

Catholic News Agency. (2021a). Pope Francis Appeals for Interreligious Harmony at Birthplace of Abraham. Catholic News Agency, CNA (06. March 2021). https://www.catholicnewsagency.com/news/246751/pope-francis-appeals-forinterreligious-harmony-at-birthplace-of-abraham

Catholic News Agency. (2021b). Pope Francis Makes Landmark Visit to Iraq's top Shiite Cleric Grand Ayatollah Ali al-Sistani. Catholic News Agency, CNA. https://www.catholicnewsagency.com/news/246748/pope-francis-makeslandmark-visit-to-iraqs-top-shiite-cleric-grand-ayatollah-ali-al-sistani

Catholic News Agency. (n.d.). Interreligious Dialogue - Latest News. Catholic News Agency, CAN. https://www.catholicnewsagency.com/tags/interreligiousdialogue

Doha International Center for Interfaith Dialogue. (n.d.). Annnual Conferences. http://www.dicid.org/annnual conferences ar/

Ghazi bin Muhammad. (2010). On "A Common Word Between Us and You". In M. Volf, Ghazi bin Muhammad, \& M. Yarrington (Eds.), A Common Word: Muslims and Christians on Loving God and Neighbor (pp. 3-17). Eerdmans.

Hick, J. (1982). God has many names. Westminster Press.

Hitchen, P. (2018). Pope Washes Feet of Inmates at Regina Coeli Prison. Vatican News (29. March 2018). https://www.vaticannews.va/en/pope/news/2018-03/popeprison-holy-thursday-lord-s-supper.html 
Huntington, S. P. (1996). The clash of civilizations and the remaking of world order. Simon \& Schuster.

Islamic Educational, Scientific and Cultural Organization. (2011). The Initiative of the Custodian of the Two Holy Mosques for Dialogue among Followers of Religions and Cultures: Achievements and Future Prospects. https://www.isesco.org.ma/wpcontent/uploads/2015/05/dialgue_followers.pdf

Johnston, D. L. (2016). Christian-Muslim dialogue in the Twenty-First Century. In R.

C. Martin (Ed.), Encyclopedia of Islam and the Muslim world (2nd ed.). Gale.

KAICIID Dialogue Centre. (2017, May 4). KAICIID Launches First of its Kind Network for Religious Christian and Muslim Faculties and Institutes in the Arab World. https://www.kaiciid.org/news-events/news/kaiciid-launches-firstits-kind-network-religious-christian-and-muslim-faculties

KAICIID Dialogue Centre. (2018, February 26). Muslim, Christian Religious Leaders Launch First Interreligious Cooperation and Dialogue Platform in the Arab World from Vienna. https://www.kaiciid.org/news-events/news/muslimchristian-religious-leaders-launch-first-interreligious-cooperation-and

KAICIID Dialogue Centre. (2019, June 13). KAICIID's Statement on the Austrian Parliamentary Vote. https://www.kaiciid.org/news-events/news/kaiciidsstatement-austrian-parliamentary-vote

KAICIID Dialogue Centre. (2021, March 5). Statement by Faisal bin Muaammar, Secretary General of KAICIID, on the Centre's relocation from Vienna. https://www.kaiciid.org/news-events/news/statement-faisal-bin-muaammarsecretary-general-kaiciid-centres-relocation-vienna

KAICIID Dialogue Centre. (n.d.). United Against Violence in the Name of Religion. https://www.kaiciid.org/what-we-do/united-against-violence-name-religion

Kayaoglu, T. (2015). Explaining interfaith dialogue in the Muslim world. Politics and Religion, 8(2), 236-262.

Kimball, C. A. (2009). Muslim-Christian Dialogue. In The Oxford Encyclopedia of the Islamic World. Oxford Islamic Studies Online. http://www.oxfordislamicstudies.com/article/opr/t125/e1642?_hi=2\&_pos=1

King, S. B. (2011). Interreligious Dialogue. In C. V. Meister (Ed.), The Oxford Handbook of Religious Diversity (pp. 101-114). Oxford University Press. https://doi.org/10.1093/oxfordhb/9780195340136.003.0008

Machado, F. (2019). Living the Christian Faith in an Inter-Religious and MultiCultural Context. https://www.vatican.va/roman_curia/congregations/cfaith/incontri/rc_con_cfai th 20190115 machado en.html

Madigan, D. (2013). Christian-Muslim Dialogue. In C. Cornille (Ed.), The WileyBlackwell Companion to Inter-religious Dialogue (pp. 244-260). Wiley Blackwell.

The Madrid Declaration. (2008). KAICIID Dialogue Centre (18. July 2008). https://www.kaiciid.org/node/1021 
Mosher, L. A. (2015). Getting to Know One Another's Hearts: The Progress, Method, and Potential of the Building Bridges Seminar. In D. Pratt, J. Hoover, J. Davies, \& J. Chesworth (Eds.), The Character of Christian-Muslim Encounter: Essays in Honour of David Thomas (pp. 512-526). Brill. https://doi.org/10.1163/9789004297210

Pratt, D. (2021). Contemporary Christian-Muslim Dialogue: Two Twenty-first Century Initiatives. Routledge.

Shafiq, M., \& Abu-Nimer, M. (2011). Interfaith Dialogue: A Guide for Muslims (2nd ed.). International Institute of Islamic Thought.

Siddiqui, A. (2018). Pope Francis, Islam, and Dialogue. In H. Kasimow \& A. Race (Eds.), Pope Francis and Interreligious Dialogue: Religious Thinkers Engage with Recent Papal Initiatives (pp. 169-182). Palgrave Macmillan.

Stott, J. R. W. (2003). Evangelical Truth: A personal plea for unity, integrity \& faithfulness. InterVarsity Press.

Tennent, T. C. (2007). Theology in the Context of World Christianity: How the Global Church Is Influencing the Way We Think about and Discuss Theology. Zondervan.

United Religions Initiative. (2012). 4th Annual International Conference on Youth and Interfaith Dialogue. https://uri.org/uri-story/20120206-4th-annualinternational-conference-youth-and-interfaith-dialogue

Volf, M., Ghazi bin Muhammad \& Yarrington, M. (Eds.). (2010). A Common Word: Muslims and Christians on Loving God and Neighbor. Eerdmans.

Weller, P. (2018). Christian-Muslim and Muslim-Christian Dialogue Initiatives, Movements and Organisations. In D. Thomas (Ed.), Routledge Handbook on Christian-Muslim Relations (pp. 423-432). Routledge.

Woodberry, J. D. (2010). Reflections on Christian-Muslim Dialogue. Fuller Studio (2010). https://fullerstudio.fuller.edu/reflections-christian-muslim-dialogue/

Woodberry, J. D., \& Basselin, R. (Eds.). (2006). Resources for Peacemaking in Muslim-Christian Relations: Contributions from the Conflict Transformation Project. Fuller Seminary Press.

World Council of Churches. (2016). Called to Dialogue: Interreligious and IntraChristian Dialogue in Ecumenical Conversation. https://www.oikoumene.org/en/resources/documents/wccprogrammes/interreligious-dialogue-and-cooperation/called-to-dialogue

World Council of Churches, Pontifical Council for Interreligious Dialogue, \& World Evangelical Alliance. (2011). Christian Witness in a Multi-Religious World: Recommendations for Conduct. https://www.oikoumene.org/en/resources/documents/wccprogrammes/interreligious-dialogue-and-cooperation/christian-identity-inpluralistic-societies/christian-witness-in-a-multi-religious-world 


\section{$\underline{\text { Appendix }}$}

\begin{tabular}{|c|c|c|}
\hline $\begin{array}{l}\text { Number of } \\
\text { Conference }\end{array}$ & Year & Theme \\
\hline $1^{s t}$ & 2002 & The Road Ahead \\
\hline $2^{\text {nd }}$ & 2003 & Scriptures in Dialogue \\
\hline $3^{\text {rd }}$ & 2004 & Bearing the Word \\
\hline $4^{\text {th }}$ & 2005 & Building a Better Bridge \\
\hline $5^{\text {th }}$ & 2006 & Justice and Rights \\
\hline $6^{\text {th }}$ & 2007 & Humanity: Texts and Contexts \\
\hline $7^{\text {th }}$ & 2008 & Communicating the Word \\
\hline $8^{\text {th }}$ & 2009 & Science and Religion \\
\hline $9^{\text {th }}$ & 2010 & Tradition and Modernity \\
\hline $10^{\text {th }}$ & 2011 & Prayer \\
\hline $11^{\text {th }}$ & 2012 & Death, Resurrection, and Human Destiny \\
\hline $12^{\text {th }}$ & 2013 & The Believing Community \\
\hline $13^{\text {th }}$ & 2014 & Sin, Forgiveness, and Reconciliation \\
\hline $14^{\text {th }}$ & 2015 & Human Action Within Divine Creation \\
\hline $15^{\text {th }}$ & 2016 & Affirming the Unity of God \\
\hline $16^{\text {th }}$ & 2017 & Power-Divine and Human \\
\hline $17^{\text {th }}$ & 2018 & A World of Inequalities \\
\hline $18^{\text {th }}$ & 2019 & Freedom: Muslim and Christian Perspectives \\
\hline
\end{tabular}


Table 2: Doha Interfaith Dialogue Conference

\begin{tabular}{|c|c|c|}
\hline $\begin{array}{l}\text { Number of } \\
\text { Conference }\end{array}$ & Year & Theme \\
\hline $1 s t$ & 2003 & $\begin{array}{l}\text { The Muslim - Christian Dialogue: Building Bridges / Scripture } \\
\text { in Dialogue }\end{array}$ \\
\hline $2^{\text {nd }}$ & 2004 & The Muslim - Christian Dialogue: Religious Freedom \\
\hline $3^{r d}$ & 2005 & $\begin{array}{l}\text { The Role of Religions in the Construction of Human } \\
\text { Civilization }\end{array}$ \\
\hline $4^{\text {th }}$ & 2006 & The Role of Religions in Building the Human Being \\
\hline $5^{\text {th }}$ & 2007 & $\begin{array}{l}\text { The Spiritual Dimension of Faith and Co-existence of Human } \\
\text { Societies }\end{array}$ \\
\hline $6^{\text {th }}$ & 2008 & Religious Values: Perspectives on Peace and Respect for Life \\
\hline $7^{\text {th }}$ & 2009 & Human Solidarity \\
\hline $8^{\text {th }}$ & 2010 & $\begin{array}{l}\text { Raising the New Generation with a foundation of values and } \\
\text { tradition: Religious Perspectives" }\end{array}$ \\
\hline $9^{\text {th }}$ & 2011 & $\begin{array}{l}\text { Means of Social Communication and the Interfaith Dialogue: } \\
\text { A Futuristic Outlook }\end{array}$ \\
\hline $10^{\text {th }}$ & 2013 & Best Practices in Interfaith Dialogue \\
\hline $11^{\text {th }}$ & 2014 & Role of Youth in Enhancing the Value of Dialogue \\
\hline $12^{\text {th }}$ & 2016 & $\begin{array}{l}\text { Spiritual and Intellectual Safety in the Light Religious } \\
\text { Doctrines }\end{array}$ \\
\hline $13^{\text {th }}$ & 2018 & Religions and Human Rights \\
\hline
\end{tabular}


Table 3: International Conference on Youth and Interfaith Dialogue

\begin{tabular}{|c|c|c|}
\hline $\begin{array}{l}\text { Number of } \\
\text { Conference }\end{array}$ & Year & Theme \\
\hline $1^{\text {st }}$ & 2009 & $\begin{array}{l}\text { Building Bridges through Interfaith Dialogue and Citizen-to- } \\
\text { Citizen Collaboration }\end{array}$ \\
\hline $2^{\text {nd }}$ & 2010 & $\begin{array}{l}\text { Building Bridges Through Interfaith Dialogue and Youth } \\
\text { Participation }\end{array}$ \\
\hline $3^{\text {rd }}$ & 2011 & $\begin{array}{l}\text { Youth Building a Common Future through Interfaith Dialogue } \\
\text { and Mutual Understanding }\end{array}$ \\
\hline $4^{\text {th }}$ & 2012 & $\begin{array}{l}\text { Harnessing the Creative and Innovative Capacities of Youth and } \\
\text { Women for Peacebuilding }\end{array}$ \\
\hline $5^{\text {th }}$ & 2013 & $\begin{array}{l}\text { The Role of Free and Responsible Media Toward a Peaceful } \\
\text { Society Imbued with Dignity and Mutual Respect" }\end{array}$ \\
\hline $6^{\text {th }}$ & 2014 & $\begin{array}{l}\text { The Role of Religions to Build Peace, Security and Counter } \\
\text { Violent Extremism in Africa }\end{array}$ \\
\hline $7^{\text {th }}$ & 2015 & $\begin{array}{l}\text { The Role of Religions to promote Peace, Security, Sustainable } \\
\text { Development and Transcend Violent Extremism in Africa }\end{array}$ \\
\hline $8^{\text {th }}$ & 2018 & $\begin{array}{l}\text { The Role of Religions to Promote Peace, Security and Transcend } \\
\text { Violent Extremism }\end{array}$ \\
\hline
\end{tabular}

